\title{
O UNIVERSO PASSIONAL DE MARINA COLASANTI, EM "A MOÇA TECELÃ"
}

\section{THE PASSIONAL WORLD OF MARINA COLASANTI, IN "A MOÇA TECELÃ"}

\author{
Mara Jane Sousa Maia \\ USP - Universidade de São Paulo
}

Resumo: Este trabalho se propõe a analisar o percurso das paixões no conto "A moça tecelã", de Marina Colasanti. Aplicamos algumas propostas teóricas da semiótica francesa, incluindo a tensividade como ferramenta de apreensão dos efeitos de sentido das qualificações modais, aspectuais e estruturais que modificam o sujeito patemizado.

Palavras-chave: literatura; figuratividade; Marina Colasanti; paixões; enunciação; tensividade.

Abstract: This study aims to examine the course of passions in the story "A moça tecelã", by Marina Colasanti. We apply some theoretical proposals of the French semiotics, including the tensivity as a tool to seize the meaning effects of modal, aspectual and structural qualifications that change the affected subject by the passion.

Keywords: literature; figurativeness; Marina Colasanti; passions; enunciation; tensivity.

Este artigo se propõe a analisar o livro "A moça tecelã", de Marina Colasanti, publicado em 2004 pela editora Global. A análise, no entanto, se restringe ao texto verbal, excluindo o visual e sua relação sincrética com o texto escrito, e focalizando a significação das paixões que moldam o percurso do sujeito. Nas relações modais iremos identificar os efeitos de sentido gerados pelos estados patêmicos.

O texto é dividido, para a análise, em três partes determinadas por mudanças de estado e mudanças tímicas do sujeito, seguindo a própria narrativa, que mostra uma sequiência de estados afetivos de forma gradual e tensiva.

É importante ressaltar que a divisão do texto é apenas metodológica, e cada parte recebe um título relacionado às afetividades desencadeadas pelos estados de junção do sujeito com diferentes objetos-valor. Os termos sublinhados são destaques do trabalho, visto que certas palavras e frases geram novos sentidos no texto, provocados pelas mudanças de estado do sujeito.

\footnotetext{
${ }^{1}$ Este conto também faz parte do livro Doze Reis e a Moça no Labirinto do Vento, Global Editora, Rio de Janeiro, 2000.
} 
O conto é narrado em terceira pessoa (debreagem enunciva), simulando imparcialidade e apagando traços de subjetividade, ao criar o efeito de distanciamento, credibilidade e veracidade, pois é alguém de fora dos acontecimentos que está contando a história. Os verbos, predominantemente no pretérito imperfeito, dão às ações uma sensação de inacabamento e duratividade.

$\mathrm{Na}$ categoria espacial, o texto mantém a debreagem enunciva, ao designar um lugar distante (alhures), característica própria dos contos de fadas. Algumas figuras discursivas reforçam e recriam esse universo mítico no texto, como palácio, jardins, carruagens, cavalos, pátios, escadas, torres, criados.

As debreagens actanciais e temporais, que criam um efeito de distanciamento do sujeito da enunciação, acontecem em momentos de mudanças de estado e de transformações dos sujeitos afetados passionalmente. Com esse mecanismo, "o discurso certamente perde em intensidade, mas ganha em extensão: novos espaços, novos movimentos podem ser explorados, outros actantes podem ser postos em cena" (FONTANILLE, 2007, p. 99). Sendo assim, ocorre uma debreagem enunciativa actancial de segundo grau, quando o interlocutor do diálogo - o homem, que deixa de ser o objeto e passa a ser o destinador - fala na primeira pessoa (com travessão) para a moça tecelã, criando um efeito de aproximação emocional e gerando relações/estados afetivos. Nesse processo enunciativo, o tempo verbal passa a ser o pretérito perfeito, simulando algo acabado, pontual e dinâmico. Apenas o espaço é mantido na debreagem enunciva durante toda a narrativa, pois se trata de um espaço "lá" ou "não-aqui".

As categorias de tempo e pessoa voltam ao processo enuncivo nos dois últimos parágrafos do conto, quando a moça restabelece seu estado inicial e o homem, destecido, retoma sua função de objeto. Há uma retomada da posição inicial, corroborando a teoria de que toda a narrativa é apenas um simulacro do mundo natural.

$\mathrm{Na}$ questão da aspectualidade, buscamos na semiótica tensiva os meios de ampliar a compreensão do texto, ao adotar um quadrado que nos permita visualizar todos os tempos verbais que o enunciador utiliza para construir as tensões passionais. Adaptando livremente nossas anotações de considerações da professora Norma Discini ${ }^{2}$, diremos que os tempos verbais ganham um "olhar" tensivo, o que podendo ser homologado com o quadrado tensivo apresentado por Luiz Tatit $(2001$, p. 156, 170). Observando com atenção a aspectualidade, podemos depreender o contínuo e o descontínuo, o acabado e o não acabado, uma abordagem que ajuda a compreensão do texto e permite ver como esse mecanismo pontua os estados passionais dos sujeitos. Os fenômenos passionais regulam o eixo da intensidade pela aspectualização das ações. Eles são "os traços aspectuais e rítmicos que caracterizam os tipos passionais" (FONTANILLE; ZILBERBERG, 2001, p.296). As anotações acima referidas são as seguintes:

Continuação da Continuação = Pretérito Imperfeito (durativo)

Exemplo: acordava, faltava, vinha, tecia, passava,...

Parada da Continuação $=$ Pretérito Perfeito (terminativo)

Exemplo: trouxe, sentiu, pensou, esperou, começou,...

Continuação da Parada = Estado (estático)

Exemplo: é, foi, tinha, era, fosse,...

Parada da Parada = Incoativo (início da ação)

\footnotetext{
${ }^{2}$ Anotações feitas durante o curso "Tópicos da Teoria da Enunciação", disciplina da pós-graduação da FFLCHUSP, ministrada no segundo semestre de 2007.
} 
No conto em estudo, os verbos no pretérito perfeito, que correspondem à parada da parada no quadro tensivo, estão relacionados a descontentamentos, em que há o fim de uma espera e o começo de uma falta, como veremos durante a análise.

\section{Quadrado tensivo:}

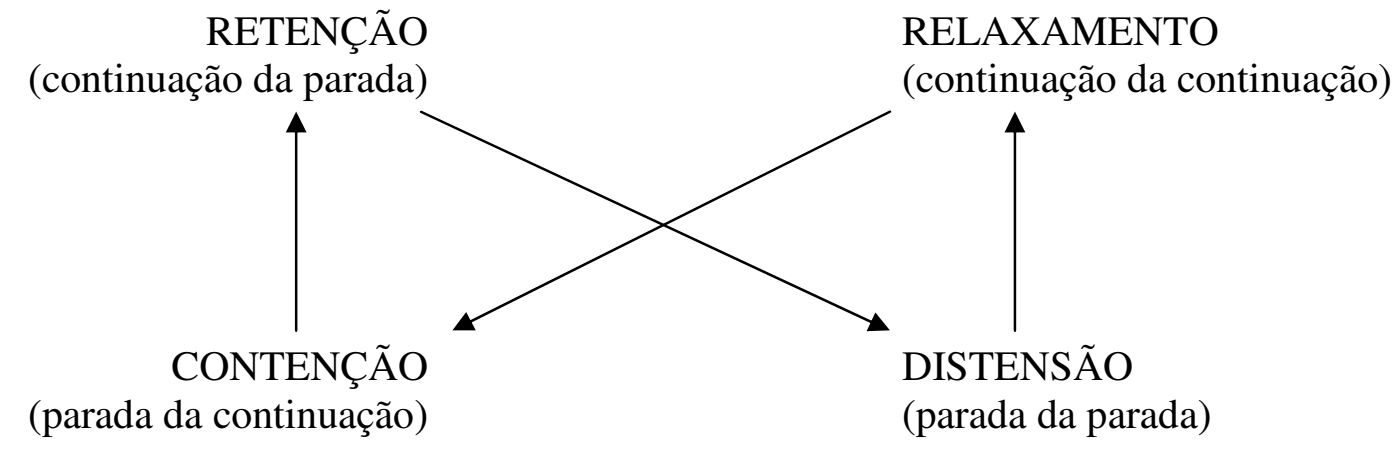

Quadro I: Quadrado tensivo.

\section{$1^{a}$ parte: Harmonia com o tempo}

Acordava ainda no escuro, como se ouvisse o sol chegando atrás das beiradas da noite. E logo sentava-se ao tear.

Linha clara, para começar o dia. Delicado traço cor da luz, que ela ia passando entre os fios estendidos, enquanto lá fora a claridade da manhã desenhava o horizonte.

Depois lãs mais vivas, quentes lãs iam tecendo hora a hora, em longo tapete que nunca acabava.

Se era forte demais o sol, e no jardim pendiam as pétalas, a moça colocava na lançadeira grossos fios cinzentos do algodão mais felpudo. Em breve, na penumbra trazida pelas nuvens, escolhia um fio de prata, que em pontos longos rebordava sobre o tecido. Leve, a chuva vinha cumprimentá-la à janela.

Mas se durante muitos dias o vento e o frio brigavam com as folhas e espantavam os pássaros, bastava a moça tecer com seus belos fios dourados, para que o sol voltasse a acalmar a natureza.

Assim, jogando a lançadeira de um lado para outro e batendo os grandes pentes do tear para frente e para trás, a moça passava os seus dias.

Nada lhe faltava. Na hora da fome tecia um lindo peixe, com cuidado de escamas. E eis que o peixe estava na mesa, pronto para ser comido. Se sede vinha, suave era a la cor de leite que entremeava o tapete. E à noite, depois de lançar seu fio de escuridão, dormia tranqüila. Tecer era tudo o que fazia. Tecer era tudo o que queria fazer.

Mas, tecendo e tecendo, ela própria trouxe o tempo em que se sentiu sozinha, e pela primeira vez pensou como seria bom ter um marido ao lado. 
O texto inicia com uma conjunção entre a moça tecelã e o tempo, bem como tudo que está relacionado a ele: as estações (chuva, calor), as unidades de tempo (dia, noite), a temperatura (quente, frio), a cronologia (hora a hora, primeira vez). Ela está em conjunção com todos esses elementos figurativizados no discurso, que relacionam seus sentimentos e seu saber (o tecer).

Os verbos acionam ações vinculadas ao tempo, como acordava, chegando, ia passando, (nunca) acabava, passava, dormia, e mantendo a coerência do texto. A moça age sempre em harmonia com o tempo, embora interfira nele com gentileza quando, por exemplo, desenha a chuva para refrescar as pétalas que sofrem com o forte calor. E sabendo que após o frio (outono/inverno) deve vir o calor (primavera/verão), ela traz/borda o sol. A interferência é feita pelo seu dom, o tecer. Ela tece a natureza, a vida, a beleza, a arte, pois são seus tapetes mágicos que ganham formas e geram vidas. Há uma duração definida pelo tempo e pelo seu trabalho manual.

Percebemos que as figuras que concretizam o tempo e o tecer dão sentido ao conto, recriando no simulacro narrativo o mundo natural e reforçando a importância da figuratividade. São figuras táteis, gustativas e visuais, relacionadas às modulações do tempo e da arte de tecer, que funcionam como "conectores isotópicos", gerando um texto pluriisotópico, com a repetição rítmica desses diferentes traços sêmicos.

\begin{tabular}{|l|l|}
\hline TRAÇOS SENSORIAIS & TEMPO E TECER \\
\hline TÁTEIS & $\begin{array}{l}\text { tear, tecer, lançar. } \\
\text { rebordava, desenhava, traço. } \\
\text { linha, fios, pentes, tapete, lançadeira, } \\
\text { algodão, lãs, felpudo, tecido. } \\
\text { vento, chuva, quentes, frio }\end{array}$ \\
\hline GUSTATIVAS & $\begin{array}{l}\text { fome, peixe } \\
\text { sede, leite }\end{array}$ \\
\hline VISUAIS & $\begin{array}{l}\text { escuro, noite, penumbra, escuridão } \\
\text { clara, cor da luz, claridade, sol, dia, manhã } \\
\text { nuvens, chuva }\end{array}$ \\
\hline
\end{tabular}

Quadro II: Traços sêmicos.

O reforço ao tempo é dado pelos substantivos (tempo, hora) e advérbios temporais (logo, depois, ainda, em breve, nunca), além da palavra durante, que pode ser adjetivo (que dura) ou preposição (no curso de, na duração de). Há ainda o uso de expressões como hora a hora e primeira vez.

Porém, ao final do texto, inicia-se uma mudança de estado do sujeito moça tecelã: ela traz o tempo em que se sente sozinha e, pela primeira vez, pensa como seria bom ter um marido ao lado. Estamos agora diante de um sujeito em falta, que passa a almejar um objeto-valor (marido). Torna-se, portanto, um sujeito modalizado pelo querer e pelo poder.

Até então, a moça tecelã era um sujeito em estado relaxado, realizado, com um éthos da justa medida, com características de pessoa gentil (sempre disposta a fazer o bem e trabalhar), prudente (esperava a própria natureza se manifestar), humilde (seguia o ritmo do tempo) e generosa (se a flor está sofrendo com o calor, por que não refrescá-la?). Convém lembrar que no livro Semiótica das paixões (GREIMAS; FONTANILLE, 1993, p. 117), a generosidade é definida como uma "disposição para dar mais do que se espera", evidenciando um sujeito desapegado, de moralização positiva. 
O destinador do sujeito moça tecelã era o tempo, ou a natureza, que a manipulava através dos ciclos sazonais. Ela aceitava esse contrato, pois lhe "parecia confiável". Mas, por um sentimento de falta, ou até mesmo por questões da moralidade que o grupo social determina, ela rompe o contrato para fazer o seu próprio tempo, preenchido com um marido e os possíveis filhos.

Sobre esse tipo de falta, Carotenuto (2005, p. 54) diz: “... viver a falta e procurar superá-la mediante a busca da totalidade perdida. Se eu me encontro numa fase em que experimento agudamente essa dor, o outro adquire o valor de uma esperança". E se ela mesma trouxe o tempo da solidão, é possível fazermos uma leitura de que a moça tecelã se sentia incompleta, um sujeito virtualizado que só se sentia pleno se formasse uma família nos moldes tradicionais da cultura em que vivia. Mas há uma segunda possibilidade de leitura: poderia ser uma pressão sociocultural levando-a a crer que, para ser feliz e completa, precisaria casar e ter filhos. Seria então o seu novo destinador a sociedade, que passa a manipulá-la.

A moça tecelã, que até então estava em conjunção com o destinador tempo/natureza, rompe esse contrato. A primeira transformação é exatamente quando ela passa a se sentir só e deseja ter um homem ao seu lado. É esse estado de falta que leva à transformação do sujeito do fazer. Mas é interessante analisar duas frases que se repetem em dois momentos do texto: "Tecer era tudo o que fazia. Tecer era tudo o que queria fazer". Sabendo do seu extraordinário talento para tecer e, com esse dom, fazer coisas tão belas e úteis, trazendo alegrias e mudanças, ela passou a crer que poderia também tecer e trazer sua própria felicidade e completude. Essa crença em si mesma desencadeou uma nova paixão, o "capricho".

Mas, antes de partirmos para a segunda parte do texto, vamos apresentar alguns conceitos semióticos a respeito da paixão. Cronologicamente, a primeira definição se firma no livro Semiótica das paixões, de Greimas e Fontanille (1993), em que eles dizem que "as paixões aparecem no discurso como portadoras de efeitos de sentido muito particulares; ele exala como que um cheiro confuso, difícil de determinar (...) emana da organização discursiva das estruturas modais" (p.21). Fontanille e Zilberberg (2001) voltam a definir a paixão, dando-lhe uma forte carga tensiva e dispondo de mais ferramentas para a análise. Para Fontanille (2007) "a paixão obedece a uma lógica tensiva (...) A maior parte dos efeitos passionais, no discurso, pode ser apreendida na perspectiva das variações de intensidade e de quantidade" (p.188). E Denis Bertrand (2003), explica que "a paixão é analisada enquanto efeito de sentido inscrito e codificado na linguagem" (p.358).

\section{$2^{\mathrm{a}}$ parte: Ruptura com o tempo}

Não esperou o dia seguinte. Com capricho de quem tenta uma coisa nunca conhecida, começou a entremear no tapete as lãs e as cores que lhe dariam companhia. E aos poucos seu desejo foi aparecendo, chapéu emplumado, rosto barbado, corpo aprumado, sapato engraxado. Estava justamente acabando de entremear o último fio da ponta dos sapatos, quando bateram à porta.

Nem precisou abrir. O moço meteu a mão na maçaneta, tirou o chapéu de pluma, e foi entrando em sua vida.

Aquela noite, deitada contra o ombro dele, a moça pensou nos lindos filhos que teceria para aumentar ainda mais a sua felicidade. E feliz foi, durante algum tempo. Mas se o homem tinha pensado em filhos, logo os esqueceu. Porque, descoberto o poder do tear, em 


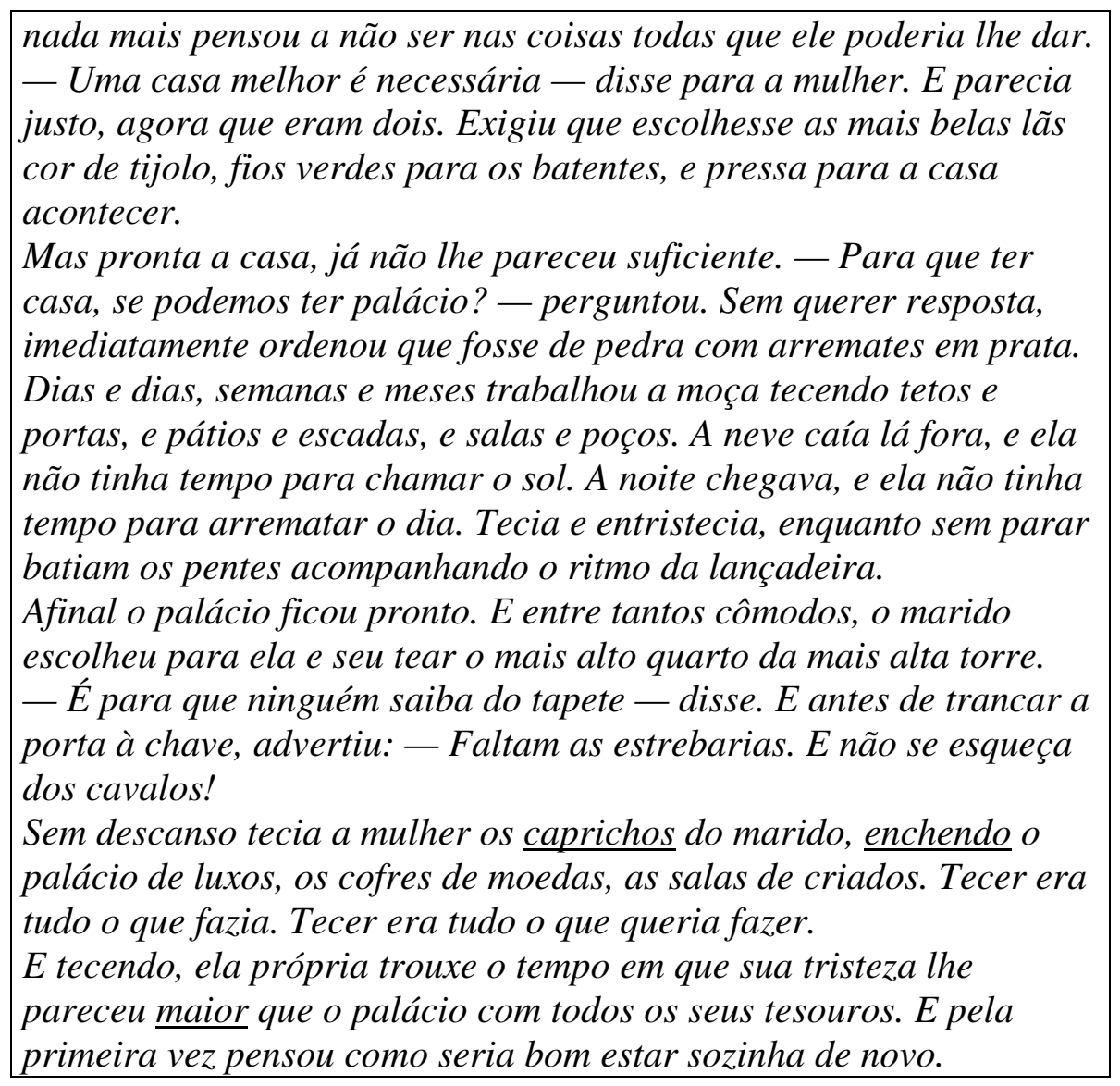

O texto começa rompendo com o tempo: "não esperou o dia seguinte". A partir daí, num primeiro momento, ela mesma determinará o que e quando fazer, atendendo apenas às suas próprias necessidades. Esse comportamento é gerado pelo sentimento do capricho. $\mathrm{Na}$ frase "com capricho de quem tenta uma coisa nunca conhecida, começou...", o substantivo capricho funciona como um desencadeador de isotopias, permitindo duas leituras:

$1^{\text {a }) ~ C o m e c ̧ o u ~ a ~ t e c e r ~ o ~ h o m e m ~ c o m ~ e s m e r o, ~ c o m ~ z e l o, ~ c o m ~ a p u r o . ~ N o ~}$ dicionário online Houaiss, a palavra pode também significar "ornamento fora do comum, mas bem executado". Por ser uma tecelã talentosa, faz seus trabalhos com caprichosa perfeição.

$2^{a}$ ) Por capricho, decidiu ter um companheiro, sendo levada pela impulsividade (traços de intensidade e aspectualidade), pela teimosia e sem justificação aparente, provocando uma mudança súbita de comportamento.

Nessa segunda leitura, podemos ter um reforço do componente passional usando mais uma vez o dicionário Houaiss, que define capricho também como "vontade repentina, sem justificativa; capricheira (ex.: c. de gente idosa, de criança, de mulher)". Por extensão, pode significar "falta de constância, de regularidade, variabilidade". "Se falta à emoção o traço duratividade, este se inscreve firmemente na paixão. Podemos admitir que a emoção se transforma em paixão quando ela molda o percurso inteiro do sujeito" (FONTANILLE ; ZILBERBERG, 2001, p. 282).

Com e por capricho, ela tece o homem que vai entrar na sua vida. Os seus bordados não só adquirem forma humana, como concretizam seu próprio desejo. Ela selecionou as lãs e as cores que dariam forma ao homem que desejava. Mas não poderia ser um marido qualquer. Ela escolheu o chapéu, o sapato engraxado, o rosto barbado, o corpo aprumado. Estamos diante de um "sujeito do capricho". Para a semiótica, o capricho pode ser um tipo de paixão, porque produz efeitos de sentido "afetivos" ou "passionais", 
transformando o sujeito. Se a paixão é da ordem do excesso, do ponto de vista da ação, vemos na tecelã um sujeito impulsivo e acelerado.

Essa paixão leva a uma ação "impulsiva", em que o sujeito age "sob o controle do poder e do querer" (FONTANILLE, 2007, p. 179). Um impulso tensivamente acelerado. E essa aceleração é concretizada nas figuratividade do texto: ela não espera o dia chegar, e o homem que ela deseja vai entrando na sua vida sem avisar, sem pedir permissão. Essa "impaciência exprime o estado iterativo de um sujeito disjunto que virtualiza, ao modo da intensidade, sua conjunção com um objeto desejado. A impaciência é uma modalidade intensiva do querer" (BERTRAND, 2003, p. 360)

E de um momento para outro, a moça se viu tomada pela paixão amorosa, pela felicidade e pela completude. Ainda em estado passional, imaginava os "lindos filhos que teceria para aumentar ainda mais a sua felicidade". O pronome possessivo, nesse caso, é restritivo. Embora a moça manifestasse querer formar uma família, suas ações e seus sentimentos são individualistas. Ter marido e filhos é apenas seu desejo caprichoso.

Encontramos aqui a concretização da paixão: um desejo caprichoso, um querer ser feliz nos moldes tradicionais da cultura, adquirindo os objetos necessários para isso. "Assim que uma paixão é identificada e denominada, não estamos mais na ordem da dimensão passional viva, mas na dos estereótipos culturais da afetividade" (FONTANILLE; ZILBERBERG, 2001, p.299). Ela é o sujeito da espera, que quer e sabe que pode ser feliz.

Ela deposita toda sua confiança nesse homem, estabelecendo com ele uma relação contratual e esperando que possa ter o que deseja. O sujeito de estado pensa poder contar com um adjuvante, mas ele logo se transformará num anti-sujeito. Assim como ela, ele pensa, deseja e quer. Quando percebe o "poder do tear", ele se torna o anti-sujeito, no papel actancial de antidestinador, ao privá-la de formar uma família com filhos. Ele não compartilha com ela o mesmo valor: "mas se o homem tinha pensando em filhos, logo os esqueceu".

Essa frase nos permite dizer que fora estabelecido um contrato fiduciário imaginário (pseudo-contrato) por parte do sujeito moça, pois "o sujeito do fazer não se encontra de maneira nenhuma engajado, sendo o produto da 'imaginação' do sujeito de estado" (GREIMAS, 1983, p. 230). Vemos que há uma relação fiduciária entre o sujeito moça e o simulacro que ela construiu, mas não é uma relação intersubjetiva:

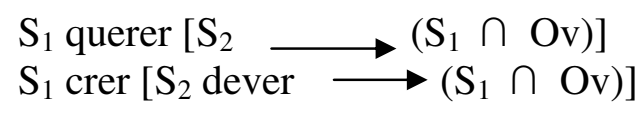

Diante da frustração de não ver seus desejos realizados pelo companheiro, ela passa a crer que os caprichos dele são justos, renunciando ao desejo materno e passando a executar as tarefas determinadas pelo marido, que agora é o seu destinador. Ao ser enclausurada, não percebe logo seu aprisionamento.

Mas, embora resignada, seu querer não foi anulado, "simplesmente adotou a hierarquia inversa, sendo o seu querer sujeito à força do seu dever" (FONTANILLE, 2007, p. 181). Essa resignação é temporária, pois logo veremos que, pacientemente, a tecelã aguarda o momento da ação. "A paciência é a disposição de espírito daquele que sabe esperar sem perder a calma" (GREIMAS, 1983, p. 232). É na ação - terceira sequência do esquema passional canônico - que está a emoção que "corresponde à crise passional que prolonga e atualiza a sensibilização: é o momento da patemização que manifesta o discurso passional" (BERTRAND, 2003, p. 374).

O homem, por ambição, passa a exigir que ela borde todos os desejos dele. Suas vontades são cada vez mais exigentes, tomando todo o tempo da mulher, que somente 
borda os "caprichos" do companheiro. São ordens, exigências, prazos e autoritarismo. Temendo a disjunção com seu objeto-valor, ele coloca a mulher e o tear na mais alta torre, fechando a porta com chave e mantendo-os isolados do mundo. Ele não compartilha os objetos-valor já alcançados nem mesmo com a mulher, que passa a ser apenas um sujeito do fazer, ou melhor, um não-sujeito cumprindo ordens. O marido também se torna um sujeito modalizado por uma paixão, a ambição, que é "forte desejo de poder ou riquezas, honras ou glórias, cobiça, cupidez" (Houaiss). Ele quer manter a conjunção com a riqueza, pelo uso que a mulher faz do tear, e seu desejo é tão intenso que não pode esperar.

Com o tempo, a moça percebe que sua tristeza é maior que seu antigo desejo caprichoso. Vê-se tomada de obrigações e sem tempo para fazer o que queria. Percebe que tudo em que acreditava não era verdadeiro, estava vivendo uma falsidade (não parecia, nem era verdade). Compreende que "tecer era tudo o que fazia" e que "tecer era tudo o que queria fazer". Somente o ato de tecer a fazia feliz, esse era o companheirismo que queria ter de volta e que a completava, pois era no tecer que ela se sentia livre, autônoma, determinando suas próprias regras e suprindo suas necessidades.

Nesse percurso, observamos que há um aumento da tensão, pois a moça começa confiando no homem que a fará feliz, mas com o tempo se decepciona, pois sabe que ele não a tornará um sujeito realizado. $\mathrm{O}$ pico da tensão se dá quando ela conclui que é melhor voltar a viver sozinha. "Ela própria trouxe o tempo em que sua tristeza lhe pareceu maior que o palácio com todos os seus tesouros". A bordadeira passa a ser um sujeito infeliz, pois sabe não poder ser feliz com aquele homem. A sua tristeza é extensa, mas vai ficando cada vez mais intensa, ao compreender que é impossível a conjunção desejada. Aquele homem passa a ser uma presença invasora e devastadora. Ela pensa então "como seria bom estar sozinha de novo".

Novas mudanças actanciais ocorrem na narrativa. O homem deixa de ser o destinador e passa a ser o anti-sujeito. E a mulher passa a ocupar o papel de destinadorjulgador, buscando restabelecer a confiança em si mesma e o estado inicial de conjunção com o bem-estar e a felicidade. Ao se reencontrar com o tempo ("ela trouxe o tempo"), percebe que era feliz quando vivia em harmonia com ele e deseja voltar a sua vida anterior, sem um marido. Só nesse momento compreende que, mesmo sozinha, era um sujeito completo, preenchido pelo tempo e pelo prazer de bordar.

No texto há uma clara relação entre desejo e linha de tempo. O desejo tem uma duração, com acelerações (a tecelã desejava tanto ter um companheiro que passa a fazer seus bordados com pressa e sem parar) e desacelerações (exausta, a moça se percebe triste e sem vontade de trabalhar no tear). O tempo se prolonga na linha da extensidade, não afetado pela explosão de paixões, de ações, de ritmos. Nele está o esvaziamento do desejo, a perda da sua potência e da sua intensidade. A intensidade e a extensidade evoluem de forma inversa uma em relação à outra. Enquanto o capricho é intenso/tônico, com picos de explosão passional, sua duração é curta. O tempo, ao contrário, tem baixa tonicidade, pois seu campo afetivo é mínimo, porém com larga extensão. "À medida que a extensão estreita-se e que a intensidade aumenta, a profundidade diminui” (FONTANILLE, 2007, p. 102). 
CASA, Vol.6 n.2, dezembro de 2008

INTENSIDADE (desejo caprichoso)

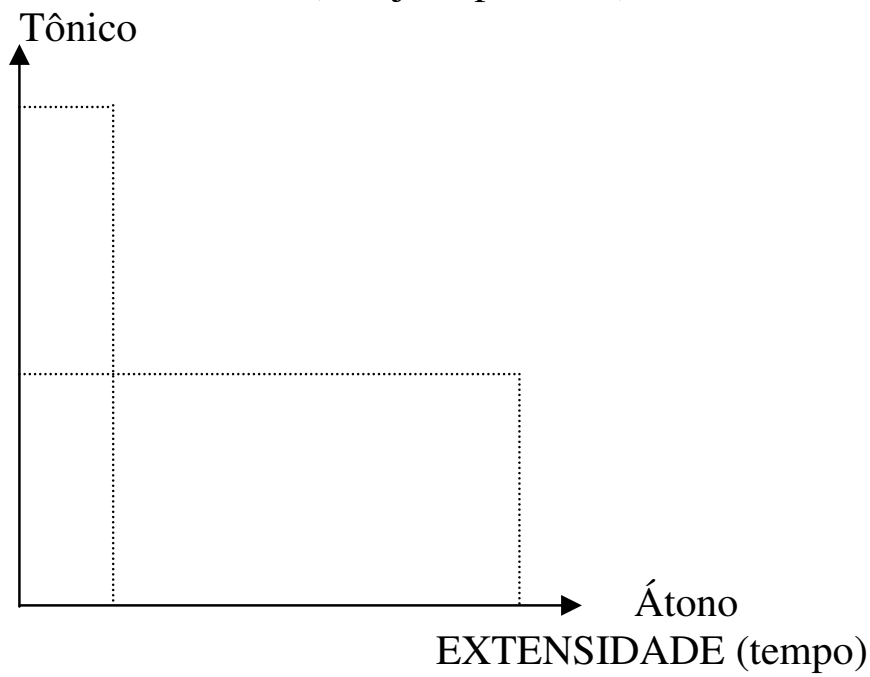

Esquema I: Intensidade e Extensidade

\section{$3^{\text {a }}$ parte: Reencontro com o tempo}

Só esperou anoitecer. Levantou-se, enquanto o marido dormia, sonhando com novas exigências. E descalça, para não fazer barulho, subiu a longa escada da torre, sentou-se ao tear.

Desta vez não precisou escolher linha nenhuma. Segurou a lançadeira ao contrário e, jogando-a veloz de um lado para o outro, começou a desfazer seu tecido. Desteceu os cavalos, as carruagens, as estrebarias, os jardins. Depois desteceu os criados e o palácio e todas as maravilhas que continha. E novamente se viu na sua casa pequena e sorriu para o jardim além da janela.

A noite acabava quando o marido estranhando a cama dura, acordou e, espantado, olhou em volta. Não teve tempo de se levantar. Ela já desfazia o desenho escuro dos sapatos, e ele viu seus pés desaparecendo, sumindo as pernas. Rápido, o nada subiu-lhe pelo corpo, tomou o peito aprumado, o emplumado chapéu.

Então, como se ouvisse a chegada do sol, a moça escolheu uma linha clara. E foi passando-a devagar entre os fios, delicado traço de luz, que a manhã repetiu na linha do horizonte.

O tempo transcorrido adquire no conto um caráter de arrependimento e de vingança, pois é a partir do momento em que a moça toma consciência de que seu desejo caprichoso só lhe trouxera sofrimento e tristeza, que decide mudar a situação, aniquilando seu algoz, o responsável por toda sua tristeza. "A vingança é um reequilíbrio dos sofrimentos entre sujeitos antagonistas" (GREIMAS, 1983, p. 241).

$\mathrm{Na}$ terceira parte do conto, a moça restabelece seu estado de conjunção com o tempo logo no início do texto: "esperou anoitecer". Ela readquire as qualidades da espera e do discernimento. Pacientemente espera anoitecer, espera o marido adormecer, confabula seus 
atos e é prudente em suas ações. Os pés descalços estabelecem uma relação com a realidade, com a lucidez.

Enquanto o homem dorme, "sonhando com novas exigências", ela começa a agir. No dicionário Houaiss, entre os significados de sonhar encontramos "ter delírios", "entregar-se a fantasias e devaneios a respeito de coisas inacessíveis ou impossíveis", "fazer castelos no ar", "desejar com insistência", "ansiar". No mesmo dicionário, temos como antônimo de ação a palavra adormecimento. Parece-nos possível fazer um paralelo entre a ação da moça tecelã e o marido que está dormindo. Enquanto está acordada, lúcida, ela tem força da ação, e ele está inerte, desacordado. A ação da mulher é dirigida por um único objetivo: anular o homem. O adormecimento tira dele qualquer praticidade e objetividade, mas amplia seus desejos e delírios. Ela está centrada e ele disperso.

É assim que ela começa a desfazer todos os bordados que eram frutos do capricho: palácio, cavalos, carruagens, criados e, por fim, o marido. Sua ação de jogar a lançadeira ao contrário para desfazer os tecidos provoca ritmos, gerando uma sensação de pulsações. Inicia com rapidez e, à medida que os objetos não desejados vão desaparecendo e seu mundo vai sendo restabelecido, as pulsações vão diminuindo de freqüência, ficando menos intensas e mais espaçadas. E, finalmente, seu estado é de relaxamento: sujeito em estado de distensão, aliviado por saber que não pode não ser.

Esse percurso registra a diminuição da tensão, chegando ao relaxamento. Ela sai do estado de grande tristeza (aspecto/profundidade) gerado pelo sentimento da falta, e cria um programa de liquidação da falta, cuja ação a leva de volta à situação inicial. Ela assume "o papel de destinador-julgador e sanciona negativamente o anti-sujeito que não cumpriu o esperado ou que exerceu um fazer contrário e prejudicial aos seus projetos" (BARROS, 1990, p.70). Sua sanção é pragmática.

A forma que ela encontra para acabar com a falta é eliminar o sujeito responsável por seu estado, criando uma paixão tensa e malevolente. A decepção a levou a querer-mal. Ela começa com o amor, mas termina com o estado passional do desamor pelo marido. "A vingança liquida a falta fiduciária, que diz respeito às relações intersubjetivas, e soluciona a crise de confiança" (BARROS, 1990, p.70).

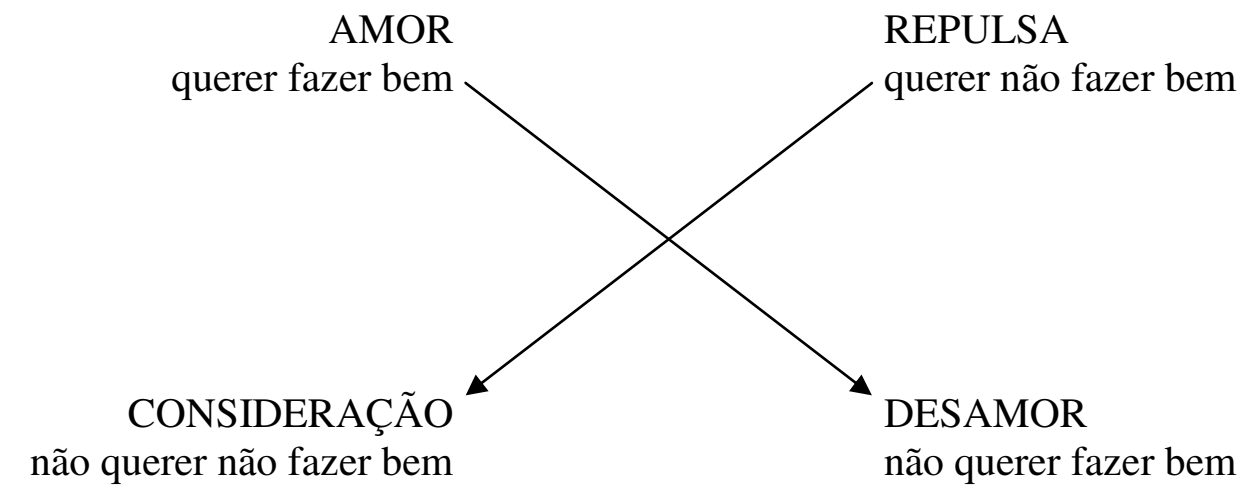

Quadro III: Quadrado semiótico II. ${ }^{3}$

O estado de paixão afeta a forma da matéria, diluindo-a num espaço-tempo, pois enquanto ela desfaz os objetos, o tempo continua e o dia chega. Seu frenesi começa durante a noite e se encerra ao amanhecer, alterando o estado das coisas e da alma. Quando o

\footnotetext{
${ }^{3}$ Ver: Paixões e Apaixonados (BARROS, idem, p.67)
} 
dia vai chegando, o marido acorda, mas sem tempo para agir, apenas vê ser corpo desaparecendo e o nada toma conta dele. Voltara a ser apenas um objeto para a moça que, quando não mais o quis, se desfez dele. Para ele, "o sono é (foi) o prelúdio da morte" (Shakespeare, em Hamlet), o início do seu fim.

Ao se desfazer do marido, a moça restabelece seu estado inicial de felicidade, completando seu percurso passional, de acordo com o modelo proposto por Diana Barros no texto Paixões e Apaixonados (Idem, p.63).

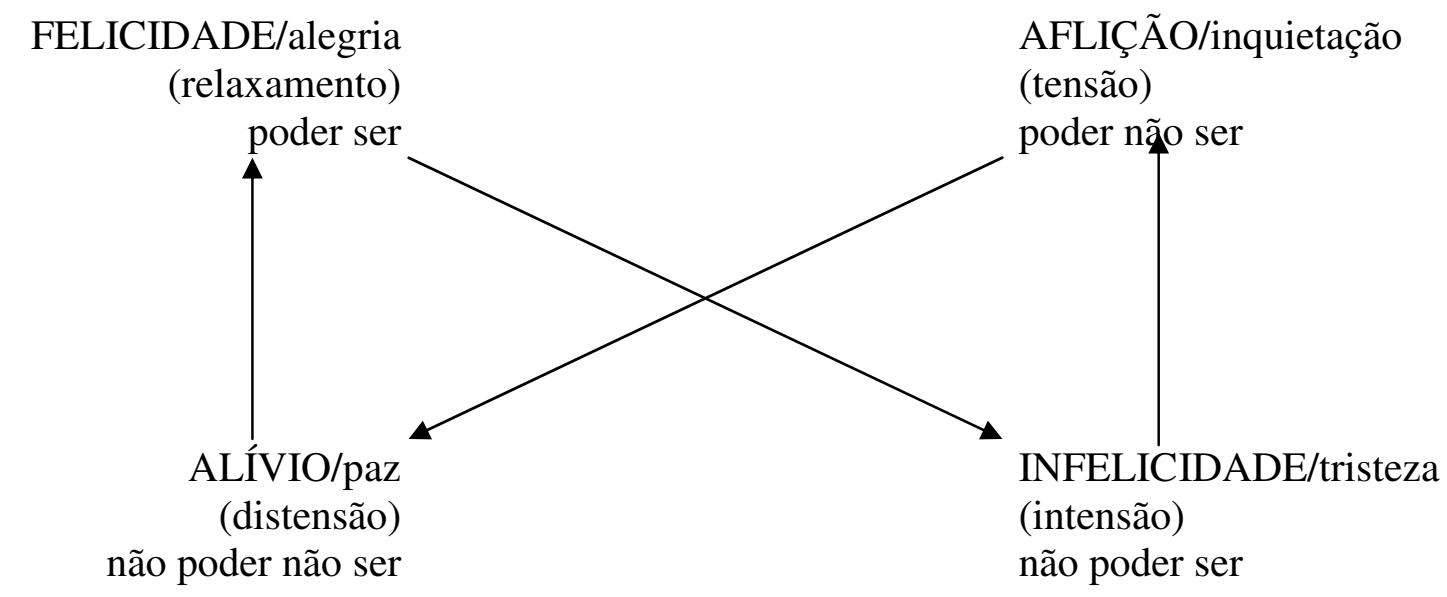

Quadro IV: Quadrado semiótico IV.

A liberdade e a felicidade chegam, para o sujeito moça tecelã, juntamente com o sol. Seus gestos são delicados e lentos. Ela está em um estado de completo relaxamento e desaceleração, pois sabe que pode ser feliz apenas fazendo seu bordado e em harmonia com o tempo.

\section{Conclusão}

Vemos neste conto de Marina Colasanti “o 'nascimento' e a 'morte' de uma paixão", mostrando "o ponto de vista do objeto, de crises aspectuais e, do ponto de vista do sujeito, suas crises fiduciárias, tanto umas quanto as outras assegurando ou não a continuidade passional" (FONTANILLE; ZILBERBERG, 2001, p. 277).

Para mostrar o estado passional, duas dimensões são afetadas no texto, a modal e a fórica. A modal envolve as competências do sujeito (querer, dever, saber, poder, crer), e a foria atua na intensidade e extensidade, projetadas na aspectualidade (tempo e espaço) e gerando efeitos rítmicos.

O capricho se mostrou intenso e pontual, com duratividade curta, firmando-se como uma paixão que moldou o percurso do sujeito. Constatamos esse estado passional quando analisamos a aspectualidade, a modalidade e a tensividade. Nessa paixão, falta ao sujeito patemizado constância e regularidade. Seja por impulso ou por vontade repentina, o capricho tem duratividade pequena, mas com picos de intensidade (tonicidade). Ele "chega" rápido, mas sua duração é breve.

Afetado por essa paixão, o sujeito moça tecelã é modalizado pelo querer/poder, estabelecendo um contrato fiduciário com o sujeito marido, que seria o responsável por dar-lhe o objeto-valor família/filhos. Ela acreditava que ele poderia e faria isso. Mas se ele prometeu (fórmula condicional), logo esqueceu. Sua promessa ficou abalada, 
caminhando para a ameaça. Como antidestinador, passa a manipulá-la pela promessa-ameaça. O programa de uso passa a ser "a eficácia da palavra", exatamente quando ocorrem as debreagens de segundo grau no texto, dando voz direta ao ator discursivo homem.

Mesmo diante da pressão gerada pelo seu manipulador-algoz, a moça percebe que, embora a ameaça seja grande, a confiança em seu manipulador é mínima, o que possibilita a disjunção entre a moça e o rapaz. Ela nota o quão frágil e efêmera é sua relação com aquele homem. Ela não mais crê na possibilidade de ser feliz e ficar em conjunção com o marido. Sua convicção é forte, não "hesitando em sacrificar o objeto que busca, a fim de permanecer na fase afetiva que escolheu para sua existência" (FONTANILLE; ZILBERBERG, 2001, p. 292).

O conto mostra uma seqüência de estados patêmicos, em conjunção e em disjunção com o objeto-valor, entre crer e não crer no destinador/manipulador, face às valências tensivas impostas ao valor do objeto e à sanção dada. A ruptura da tecelã não é feita somente com o marido, mas com os valores determinados pela sociedade em que uma mulher só é feliz se casar e tiver filhos. Essa moça provoca a quebra de um estereótipo cultural, em que a mulher tem uma postura passiva diante do seu papel/função social. Seu "éthos prédiscursivo" é de uma mulher submissa e cumpridora das regras estabelecidas pela sociedade. No início, ela se apresenta com um éthos da justa medida (estereotipado) mas, ao se ver em falta, decide tomar as rédeas de sua vida, assume o papel dominante e julgador, passando a ter um éthos hiperbólico, com ações extremas.

Ela é um sujeito da ordem do inacabamento, rompendo com "um modelo préconstruído", com papéis que a sociedade pré-determina para a mulher. O dever deixou de reger o querer, permitindo a mobilização do sujeito na sua esfera de comunicação. É também da ordem da ambivalência, pois mesmo ao adotar ações abruptas e extremas (aniquilou o marido e eliminou todos os objetos provenientes do capricho), manteve um "tom de voz" sereno. Apenas sorriu quando se viu em disjunção com o que não queria, e delicadamente voltou a fazer o que sempre fez e quis.

Mesmo na situação de falta, a moça tecelã decidiu que queria e poderia ser

feliz. Percebeu que a felicidade pode ser construída de várias maneiras, dependendo apenas das escolhas e do olhar do sujeito.

\section{Referências bibliográficas}

BARROS, D. L. P. de. Paixões e apaixonados: exame semiótico de alguns percursos. Cruzeiro Semiótico, n 11-12, janeiro, 1990, Porto, Portugal.

BERTRAND, D. Caminhos da semiótica literária. Tradução do Grupo CASA. Bauru, SP: EDUSC, 2003.

CAROTENUTO, A. Eros e pathos: amor e sofrimento. Tradução de Isabel F. L. Ferreira. São Paulo: Paulus, 2005, $2^{a}$ edição.

Dicionário online Houaiss (http://houaiss.uol.com.br/busca.jhtm). Acesso em 02 jan 2008.

FONTANILLE, J. Semiótica do Discurso. Tradução de Jean Cristtus Portela. São Paulo: Contexto, 2007. 
CASA, Vol.6 n.2, dezembro de 2008

FONTANILLE, J. \& ZILBERBERG, C. Tensão e Significação. Tradução de Ivã Carlos Lopes, Luiz Tatit e Waldir Beividas. São Paulo: Discurso Editorial Humanitas/FFLCH/USP, 2001.

GREIMAS, A. J. \& FONTANILLE, J. Semiótica das Paixões. Tradução de Maria José Rodrigues Coracini. São Paulo: Ática, 1993.

Da Cólera: estudo de semântica lexical (tradução livre do texto "De la colère: étude de sémantique lexicale”, p. 225-246), em Du Sens II, Essais sémiotique. Paris, Seuil, 1983.

TATIT, Luiz. Análise semiótica através das letras. São Paulo:Ateliê Editorial, 2001. 